\title{
Plaque Forming Unit per Milliliter
}

National Cancer Institute

\section{Source}

National Cancer Institute. Plaque Forming Unit per Milliliter. NCI Thesaurus. Code C71199.

A unit of potency of a biological product expressed as a quantity of viable infectious entities capable to produce a cytopathic effect in the appropriate cell culture per one milliliter of the preparation. 